\title{
유엔지속가능발전 정상회의(Rio+20)
}

\section{I . 회의개요}

유엔지속가능발전 정상회의(Rio+20) 가 2012년 6월 20일부터 22일까지 리오데자네이루에서 개최됨.

\section{II . 주요내용}

- 브라질 의장(결과문서 채택이후 폐회식 행사시 지우마 대통령이 참석) 주재하에 개최된 폐 회식에서 참가국들은 만장일치로 결과문서 “The Future We Want” 를 채택하는 결의 및 금번 회의 주최국인 브라질에게 사의를 표명하는 결의(G77 발의)를 채택하고 , 아울러 회 의 결과 보고서를 채택함.

- 결과문서 채택 이후, 볼리비아, 니카라과 등 Alba 그룹 국가들은 Green Economy가 각 국의 개발 정책을 저해해서는 안된다고 하면서 동 정책을 수용할 수 없다는 취지로 발언하 였으며, G77(알제리), $\mathrm{EU}($ 덴마크), 아프리카 그룹(DR콩고) 등도 녹색경제, UNEP 전문기 구화 등에 대하여 기존의 입장을 재차 발언함.

- 아이슬란드, 노르웨이, 미국은 결과문서에 여성의 재생산권이 반영되지 않은데 대해 아 쉬움을 표명하였으며, 교황청은 낙태를 포함하는 여성의 재생산권의 개념을 받아들일 수 없다는 입장을 표명함.

- 베네주엘라 대표는 자국의 입장에 반대한다는 이유로 회의장 밖에서 비정부기구인 Green Peace로부터 언어적, 물리적 상해를 입었다고 하면서 유엔사무국과 의장국 브 라질이 동 사건에 적절히 대응해 줄 것을 요구한 바, 의장은 유엔 사무국이 적절한 조치 를 취해줄 것을 권고함.

- Rio +20 총회 사무국장인 Sha Zukang은 지난 2 년간의 회의 준비기간 중 지속가능발전 을 위한 전 세계 모든 국가의 의지를 확인할 수 있었다고 평가함.

- 반기문 사무총장은 결과문서가 향후 지속가능발전 방향을 제시하고 있다고 평가하고, 금번 회의 결과를 바탕으로 앞으로 지속가능발전을 위한 새로운 도약을 시작해야 할 때라고 하 면서 모든 회원국의 통합된 노력을 촉구함. 
- 지우마 대통령은 폐회사를 통해 이번 회의의 결과문서는 모두 다른 입장을 갖고 있는 각국 이 총의(consensus)로 합의한 만큼 더 의미가 있으며, 이번 회의를 통해 합의한 지속가능 발전목표(SDGs)로 설정, 지속가능발전을 위한 제도적 강화 방안, 해양보호구역 이원의 생 물다양성 보전에 관한 협의 개시 등을 성실히 이행함으로써 전세계의 지속가능발전 실현을 위해 노력할 것을 촉구함.

\section{III. 관찰 및 평가/건의}

• 지속가능발전에 대한 전세계의 의지 확인

- 지속가능발전이 경제위기, 사회적 불안정, 기후변화, 빈곤퇴치 등 범지구적 문제에 대한 유일한 해결책임을 재확인하고, 각국의 행동을 촉구

- “녹색경제” 로의 새로운 패러다임을 제시

- 녹색경제가 지속가능발전의 중요한 수단임을 확인함으로써 UN 차원에서 최초로 녹색 경제를 새로운 발전 패러다임으로 제시

- 지속가능발전의 포용적 성격 강조

- 지속가능발전을 위한 여성, 아동, 원주민 등 사회적 약자의 역할을 강조하고, 민-관 파 트너십 강화를 통한 포용적 지속가능발전 촉구

- 지속가능발전목표(SDGs) 설정절차에 합의하여 개발의 새로운 개념 제시

- 각 국 정상은 SDGs 설정에 대한 기대감을 표시하고, post-2015 개발 어젠다와의 연계 를 촉구, 향후 지속가능발전이 개발의 새로운 지표를 제시할 것으로 기대

- 녹색경제/ 지속가능발전에 대한 입장차 확인

- 선진국들은 신기술개발 및 일자리 창출 기능 등 녹색경제의 역할을 인정하고 모든 참가 국의 녹색경제로의 전환을 촉구

- 개도국들은 "공통의 차별화된 책임(CBDR)" 을 강조하며 선진국들의 선도적 노력을 촉 구, 녹색경제는 하나의 정책 옵션임을 주장하고 개도국에 대한 기술, 재정적 지원 증대 를 요구

- $\mathrm{UNEP}$ (유엔환경계획) 전문기구화에 대한 이견 확인

- 참가국은 국제 환경 거버넌스 강화에 대한 공감대를 형성했으나, 환경관련 전문기구 설 립에는 이견 노정

- EU 및 아프리카 정상들은 UNEP 전문기구화 실패에 대한 아쉬움 피력 